\title{
The impact of the Programme for International Student Assessment (PISA) on aspects of education policy reform in Germany
}

\author{
Nitin Rughoonauth \\ n.rughoonauth@uom.ac.mu \\ Department of Physics, Faculty of Science, University of Mauritius
}

\section{Abstract}

The poor performance of German students in PISA 2000 was a wake-up call for Germany, with the students' scores in reading, mathematics and science being considerably lower than the OECD average. The immediate reaction to the disappointing results, dubbed the German "PISA shock", stimulated a heated public debate and a strong policy response, with the German government enacting reform measures that led to significant improvement in the country's educational performance. One of the core elements of the reform was the passage from the German Bildung, which is an education philosophy based on the development of the individual rather than on specific functional abilities, to a notion where educational standards and assessment of students' achievements are central. Another crucial intervention was to define standards for teacher education, which led to a critical reflection on the quality of teacher training. In this article, we propose to review those measures, while touching upon others, of the German educational reform following the publication of the PISA results.

Keywords: PISA; Germany; education reform; standards; assessment; teaching education 


\section{Introduction}

International large-scale assessments (ILSAs) are surveys carried out every few years to measure the educational achievement of learners of particular age groups in one or more learning areas. During the last three decades, due to a shift in assessment culture (PizmonyLevy, 2013; Martens, 2007) and an international education policy space increasingly dominated by comparative performance data (Nóvoa \& Yariv-Mashal, 2003; Henry et al., 2001), ILSAs, such as the Organisation for Economic Co-operation and Development (OECD)'s Programme for International Student Assessment (PISA), have gained significant traction in influencing education systems worldwide. Countries participating in such assessments have continuously reviewed their education practices based on standards and recommendations emerging from ILSAs - although questions remain about the validity of international comparisons in performance (Hanberger, 2014; Ozga, 2012) - so as to enhance the overall quality of their education. In this article, we will look at the impact of PISA on the German education system at the turn of this century.

\section{PISA and policy reform}

The PISA study, which was first carried out in 2000 and every 3 years thereafter, measures, within an internationally agreed framework, "15-year-olds' ability to use their reading, mathematics and science knowledge and skills to meet real-life challenges" (OECD). Its aim is to provide comparable data that enables participating OECD member and non-member countries to improve their educational outcomes. By building on the concepts of literacy and competencies, PISA assesses the applicability of learned skills instead of curriculum knowledge (Carvalho, 2012). Collectively, the OECD's extensive range of PISA resources has helped make the study's results more significant for policymakers than those of other ILSAs 
(Volante, 2016), although the rationales for using such data to guide policy are seldom articulated, understood or contextualised, leading to issues of consequential validity when dramatic, large-scale educational reforms follow (Feuer, 2013). Still, analysis by Grek (2009) and Breakspear (2012) found that over $80 \%$ of PISA participating countries reported some degree of influence on their education policies. Compared to other participating countries, Germany has shown "one of the strongest reactions to PISA" (Niemann et al., 2017, p. 176), an effect commonly referred to as the German "PISA shock". Whether the Germans were in the grip of a lingering Dunning-Kruger effect (Kruger \& Dunning, 1999) leading to an ignorance of issues in their education system, the PISA 2000 results had the effect of shaking off the emperor's clothes. However, the PISA was not the first study that revealed deficits in German education. Yet, it was the first to trigger a fundamental public debate on education (Martens \& Niemann, 2013) that was previously non-existent in Germany (Gruber, 2006; Wiseman, 2013) and make a difference in terms of stimulating comprehensive education reforms (Niemann, 2016).

\section{German reaction}

As initial reaction to those results, three major objectives were pursued to address the weaknesses of the German education system: (1) carefully analyse the state of the system; (2) trigger a discourse among education stakeholders; and (3) implement overarching measures (Sälzer \& Prenzel, 2014). As a common foundation, the Standing Conference of the Ministers of Education and Cultural Affairs of the federal states (German acronym: KMK), which is a group of state ministers in charge of education, research and cultural affairs, agreed on seven fields of action (KMK, 2002): (1) improving pre-schoolers' language proficiency; (2) harmonising preschool and primary education; (3) improving primary-level proficiency in reading, mathematics and sciences; (4) supporting disadvantaged children; (5) improving 
school development, including educational standards and evaluation; (6) enhancing professional teacher education; and (7) establishing all-day schools (Sälzer \& Prenzel, 2018). In this article, we will cover actions (5) and (6), although aspects of some of the others will be touched upon along the way.

\section{Post-PISA Educational Monitoring in Germany}

In line with the KMK's comprehensive strategy for educational monitoring (KMK, 2016), all German federal states opted to regularly participate in or conduct comparative competencebased studies using standardised tests on three levels. For a start, grade 10 students would continue to participate in the ILSAs; secondly, national standardised assessments would be administered to grades 4 and 9 students every 5 and 3 years, respectively, to assess whether educational standards are being met at the level of the state; and thirdly, standardised statewide "comparison tests" (German: VERgleichsArbeiten, VERA) would be used to determine achievement levels of all grades 3 and 8 students every year, serving as performance feedback to schools. These forms of assessment are characterised differently according to their respective purposes and who they assess. While on one hand the international and national assessments were designed to monitor the educational system at large and at state level, the state-wide comparison test on the other hand provides teachers with important information on the strengths and weaknesses of learners with respect to the educational standards. Hence, taken altogether, these assessments form part of a framework that has made it possible to systematically monitor the quality of education in Germany at primary and lower secondary levels. Underlying this is a complex system of internal and external accountability involving teachers, schools, states, and the federal government. Here, we will be mainly concerned with 
certain aspects of validity and accountability with respect to the national standardised assessments and the VERA.

\section{National Education Standards and Standardised Assessments}

Before the PISA study, the notions of national education standards (NES) and standardised assessments (SAs) were controversial and largely absent in Germany (Lundahl \& Waldow, 2009). However, results from Germany's participation in ILSAs indicated that the tendency to drive educational performance based on curricula, allocation of resources and administrative guidelines alone, was not leading to expected results; a shift of focus onto the effects and results of educational processes was necessary. Thus, during the late 1990s, SAs and the idea of adopting NES which set out desired learning outcomes that students were meant to achieve, slowly gained popularity, with the 16 federal states agreeing in 1997 on instituting such NES. After the publication of the PISA 2000 results, the KMK introduced mandatory NES at the primary and secondary levels in tandem with SAs based on OECD recommendations (Neumann et al., 2010) to, among other things, guide the development of curricula that would ensure coherence of education requirements within the school system, and initiate teacher training. As such, much of the activity related to standard setting preceded the PISA findings, to which references only served as further legitimation in policy deliberations.

The Institute for Educational Quality Improvement (German: Institut zur Qualitätsentwicklung im Bildungswesen, IQB) was established in 2004 to support all states in developing assessment frameworks and conducting tests to improve and assure the quality of the German education system. Since its inception, the IQB has been in charge of setting standards and using those to systematically develop models of proficiency levels for interpreting test results. The introduction of the NES was accompanied by a prolonged and intense discussion on the state 
and prospects of education in Germany (Klieme et al., 2003). It was feared that reliance on PISA results for policy decisions would lead to a normative type of education (Jürgens, 2004). PISA's assumption that schools should produce human capital to meet the needs and expectations of a global labour market (Bennett, 2006, p. iii), and its emphasis on scientific literacy (Roberts, 2007; Bybee et al., 2009), could be seen as being detrimental to the notion of scientific literacy as a socio-scientific issue (Sadler \& Zeidler, 2009). Linked to this is the risk of overlooking school subjects that are not part of the basic education defined by PISA, such as arts, history, music, philosophy, and social sciences (Raidt, 2010), thus presenting the danger "that educational standards undermine an enriched education" (Schönig, 2007, p. 494).

Standard setting involves establishing clear criteria that would delimit proficiency levels (Cizek \& Bunch, 2007). This process entails systematically analysing the demands of items, at a cognitive level, which students with a given test score would have answered correctly (similar to figuring the differential item functioning of the item). This then makes it possible to come up with qualitative features of the demonstrated competencies, and can be used to predict achievement. To ensure that interpretations of test results based on standards can be rigorously justifiable (Decker \& Bolt, 2008), inferences made from those results must be supported by sufficient validation evidence (Kane 1992, 2009; Messick, 1995). Thus, using standards-based assessments requires that questions about validity can be answered scrupulously, as the uninformed use of results of these assessments can have consequences, both at the levels of students and teachers, at the school organisational level, and at the administrative level of the system. 
That standard-setting has followed OECD recommendations based on PISA findings raises certain issues. Whether it is reasonable for an organisation focused on economic development to assume an epistemic status on establishing standards and development of national assessments could be contentious. Given that attempts to establish a proper validation of proficiency levels failed (Prenzel et al., 2011) and that validated proficiency levels did not exist at the time lower secondary level NES were formulated in science subjects, standards ended up being framed by PISA and the identified deficits of German science education. It is not hard to imagine that such standards would emphasise those learning domains and competences assessed in the PISA study, and thus drive teaching and learning practices towards test performance instead of quality education. National assessments based on standards are thought to be central to quality assessment and quality development (Neumann et al., 2010). In the case of NES, there appears to be an emphasis on quantitatively measuring learning outcomes, and the priority given to learning objectives over socialisation objectives (Osborn, 2006) in conjunction with the notion of skills as understood in economic terms, sets up a system of test-based accountability that could lead to a situation of what O'Neill (2013) calls "the accountability tail wagging the educational dog". Here, the "accountability tail" would be the OECD and PISA and the "education dog" would be the German education system.

\section{VERA and educational monitoring}

In 2004, the VERA (VERgleichsArbeiten [comparison tests]) programme was implemented in all states by the IQB to investigate the competences achieved by grades 3 and 8 learners so as to provide school actors with evidence-based information on what to improve to meet the "performance standards" (Herzog, 2013) used to set the expected levels of a certain skill or 
competency to be attained by a certain point in time. These tests were to function differently from the ILSAs and the SAs. Although VERA test items would be produced and trialled at the national level under the IQB's leadership, each state was to use their "own regulations to organise the way they [...] prepare their tests, run them, analyse them and give feedback on the results" (IQB). VERA thus would seem to advocate a "new form of interplay between accountability and school autonomy" (Demski \& Racherbäumer, 2017, p. 82), where states, schools and teachers would assume responsibility for gathering and using evidence on the level of achievement of their students to improve teaching and learning practices. That this process would take place in the year preceding the national SAs in grades 4 and 9 would presumably benefit school actors aiming to prepare their students for the SAs. However, such is not quite the case, as we will see below.

\section{Purposes of VERA and function creep}

VERA results of individual schools would not be published publicly for comparison purposes, but could be accessed by "school supervisors and inspectors", thus allowing for the possibility of teachers and schools being held accountable for their students' levels of attainment. In 2010, the KMK published a standards-based teacher-development concept explaining the pedagogical potential of VERA for educators, where the tests' results would give them "an 'outsider's view' [...] for comparing learning progress in their own class", allow them "to improve their diagnostic skills", "justify and plan pedagogical interventions and support measures", and improve "instruction in subject-specific department in schools" (IQB). That a single test is to be used for so many purposes, in particular where there is no overlap in the information required in each case (Morris, 2011), could constitute certain risks, e.g. one or more purposes could be overemphasised to the detriment of others, thus undermining the validity of the assessment and jeopardising the constructive use of the test's results (OECD, 
2013). This would, for example, be the case if teachers, because of accountability pressures, were to use VERA to only measure the achievement level of their students, and not use the results for instructional adjustments which would be time-consuming. In other words, one should not use an assessment set up for diagnostic and formative purposes as an accountability tool as this may corrupt its primary function (Linn, 2000). Also, that the test is being used for many purposes can lead to a gradual widening of the use of that test beyond that set of purposes for which it was intended, a phenomenon known as "function creep" (Pant et al., 2017).

\section{Proficiency levels and validity}

Schönig (2017) states that another aim of the VERA would be to "allow a comparison of performance and skills among schools classes, schools and German Länder" (p. 217), a proposition hard to reconcile with the possibility of those states setting significantly different tests leading to results that a priori could not be compared. Furthermore, any interpretation of the VERA results could likely succumb to the usual threats of validity, which are constructirrelevant variance and construct underrepresentation, due to poorly designed tests or other test irregularities, such as test item bias, and the possibility that teachers could focus instruction to improve test results due to accountability pressures. State-, school- and classspecific contexts and characteristics, some of which are strong indicators of student achievement (Ertl, 2006), would undermine any comparative use of the VERA. Another aspect affecting the validity of the competency test results - the accuracy of classification of proficiency levels - was studied by Pant et al. (2017) in the context of English as a Foreign Language in VERA in Grade 8. As summarised in Wyse (2010), a number of factors are known which affect classification accuracy, over and above the typical errors due to sampling and measurement in estimating student ability (Betebenner et al., 2008). These include the 
underlying ability distribution and population of test-takers (Lee, 2010), the number of proficiency levels across an ability scale, the reliability of estimates of the test-taker's ability (Ercikan \& Julian, 2002), the ability spread between cut scores (Zhang, 2010), and the number of test-takers whose estimates of ability cluster around a cut score (Emons et al., 2007). Pant et al. (2017) found that the accuracy of classification of proficiency levels could compromise the "validity of inferences drawn at smaller aggregate levels like schools or classes where trend information about changes in proficiency level distributions may become the focus of interest for teachers and principals" (Pant et al., 2017, p. 64). Furthermore, attempts to finegrain the feedback by increasing the number of proficiency levels would lead to a significant decrease in classification accuracy. Thus, teachers wanting to use the VERA results to better diagnose the ability of students could run the risk of getting the wrong information.

\section{Limitations of VERA}

Since its inception, the VERA programme has suffered from several operational shortcomings. None of the states have managed to implement a coherent support system for teachers and school administrators that would, in the first place, enable them to understand performance results, then use those as feedback to inform appropriate instructional and organisational interventions (Pant et al., 2017). A possible fundamental issue here could be that performance standards are being used instead of "opportunity-to-learn-standards" (Herzog, 2013) which would determine the resources (teaching and learning aids, classroom equipment, etc.) that would provide students with an environment conducive for learning. Studies looking at teachers' use of data in improving pedagogy have shown significant variation in how they reflect upon and use information based on evidence (Böttcher \& Keune, 2012; Kühle \& van Ackeren, 2012). Although policy calls for the use of evidence, it has been shown that data cannot easily be translated into evidence-based practice (Fleischman, 2009), 
as "people must actively make meaning of the data and construct implications for action" (Coburn \& Turner, 2001, p. 117). A study by Maier et al. (2012) has shown that a significant number of teachers and principals have shown reservations about the extent to which the state-wide tests are useful. Many of them do not use the results for improving their teaching practices (Richter et al., 2014) or organisational development (Bach et al., 2014; Wurster et al., 2013) but instead for the diagnostic purpose of evaluating students' attainment. Even there, Frühwacht finds that "VERA results are only sporadically used to confirm the teacher's own diagnosis when consulting parents" (Frühwacht, 2012, p. 206) and "hardly ever used to set up a pupil improvement programme. [...] Instead of being used as a tool to diagnose what could be improved in class teaching, test results serve to legitimise selection decisions" (Schönig, 2007, p. 219). The introduction of the VERA was criticised by “teachers and teachers' unions [...] as a waste of time counting it among the more severe illnesses of the German education system" (Fuchs, 2017, p. 229). In 2014, after a decade of VERA testing, it was reported (Schulniveau, 2014) that some of the major teachers' unions in Germany had claimed that the use of comparison tests to improve teaching had failed in its objective and had had no noteworthy influence on the development of class practices.

\section{The SINUS programme: A teacher-training initiative}

The poor results of German students in mathematics and science in the PISA 2000 study prompted stakeholders to not only introduce NES to guide the development of learners' competencies, but to also define standards for teacher education (Sälzer \& Prenzel, 2018), which led to a critical reflection on the quality of teacher training (Terhart, 2000). This revealed that teachers in pre-PISA Germany tended to teach primarily from a subject-matter perspective, thus overlooking students' learning processes and outcomes. As a consequence 
of PISA, a number of states engaged in evaluating their system of teacher training. Along with an upcoming call to focus on the development of professional competences and to set standards for teacher training, those states extended their strategy of locally evaluating teachers training colleges to a comprehensive and broad evaluation programme. Professional teaching would also imply lifelong learning and an active engagement in school development processes (KMK, 2004).

One of the most impactful measures taken to enhance mathematics and science teaching at the secondary level was the creation of the SINUS (Steigerung der Effizienz des mathematischnaturwissenschaftlichen Unterrichts [Increasing the efficiency of mathematics and science instruction]) teacher development programme. It was based on five guiding principles (Sälzer \& Prenzel, 2018) focused on the research-driven development of instructional training modules in problematic areas of mathematics and science teaching (BLK, 1997; Prenzel et al., 2009a; Prenzel et al., 2009b), on continuous professional development in quality teaching and learning (Walke, 2007), on teacher-teacher cooperation within and across schools (Batzdorfer \& Kullmann, 2016; Ostermeier et al., 2010; Terhart, 2001; Sammons, 1999), on pedagogical content support, and on the evaluation of the effectiveness of the programme.

\section{SINUS and assessment}

The content framework of SINUS spans eleven modules (Prenzel et al., 2009b), each of which covers one problem area that is particularly relevant to teachers, and provides possible timely solutions to the problem. Two of these modules actually relate directly to our previous discussions about assessment and educational standards. The one on assessment (module 10; see Prenzel et al., 2009b, pp. $43-46$ ) promotes the development of a test culture that involves "examining the quality of test tasks used and establishing whether they really test 
the students on what they should be learning" (p. 43), thus touching upon the aspect of construct validity in assessment. The teachers are also taught different approaches to providing feedback on proficiency levels. Altogether, these skills support them in their understanding and use of the VERA competency-based tests. The module on quality assurance (module 11; see Prenzel et al., 2009b, pp. 47 - 49) covers the development and assurance of quality in mathematics and science instruction through three steps: (i) establishing standards by formulating desired competencies; (ii) developing quality tasks and lesson units, and constructing test items based on those standards, and (iii) understanding the test results and using them to improve instruction. These relate to the evidence-based approach to determining learners' proficiency, using SAs, with respect to competencies defined in the NES. Hence, the training teachers would be getting in those two modules should in principle better equip and support them in translating the NES into instructional targets and strategies, and in making valid inferences from the results of the SAs and VERA that would inform their teaching.

\section{Success of SINUS}

By comparing student performance in schools where teachers were trained in the programme (SINUS schools), with that of schools where teachers were not, it was found that students attending SINUS schools, in particular those previously identified as having the most pronounced need for improvement, performed significantly better than students in the other schools, with students from the former expressing greater interest and positive attitudes towards mathematics and science (Prenzel et al., 2005). Due to the success of SINUS, a modified version of the programme was implemented at primary level. Primary schools were subsequently evaluated and found to perform significantly better in mathematics and science (Dalehefte et al., 2014). Those, and possibly many more such, findings could be seen to 
provide support for the impact of SINUS on the teaching quality, but one underlying danger with this simplistic connection being drawn between achievement of students and the actions of teachers is that it might be based on flawed assumptions. In some of those studies at least, it may be that a number of teachers who have been trained were already using the right approaches in their teaching, and their students would have performed better irrespective of the training. Another would be to assume that all other factors that could have affected achievement (e.g. socioeconomic status of students, teaching and learning facilities, etc.) would have been accounted for, which is unlikely. Brophy and Good (1984) pointed out that "in the case of correlations between teacher behaviours and achievement, positive correlations do not necessarily indicate that the teacher behaviour should be maximised" ( $p$. 127). For example, if a teacher is trained in using group work as a teaching method, that this method may lead to students' learning would not mean that the teacher will maximise the use of group work, to the expense of, say, individual learning. In other words, one has to exercise caution in interpreting reports like the ones above, not to diminish the potential of such a programme, but to be critical about what it can actually achieve.

\section{Teacher accountability}

There is a tendency to think, in teacher education policymaking, that the knowledge of teachers and what they can accomplish with it is the single most important influence on what students learn (Darling-Hammond, 1998; Darling-Hammond \& Sykes, 1999). The SINUS programme, after all, ascribes itself to the logic that accountability would improve teacher education quality, which would enhance teacher quality (as measured in terms of students' achievement). Since PISA 2000, and even before, the rhetoric has been that Germany's competitiveness depends on the ability of its teachers to teach all students relevant knowledge and skills. The dominant accountability paradigm in teacher education in Germany, 
like in many countries participating in ILSAs, seems to have been animated by a key idea derived from a market ideology championed by organisations like the OECD and instrumentalised through ILSAs. Concerns about the quality of teacher education have created a kind of echo chamber among policymakers and education reformers about the importance of teacher quality defined in terms of impact on students' performance on national and international comparisons. Furthermore, there seems to be a commitment, inherent to this accountability paradigm, to equity in giving all learners access to quality teaching by closing the teacher quality gap (Peske \& Haycock, 2006). However, this appears to be premised on two assumptions (Cochran-Smith et al., 2018): (i) that the teacher quality gap is a major cause of educational inequity, and (ii) that increasing supply and equalising the distribution of teacher quality will achieve equity. In a country where there is a considerable number of migrants living in low socioeconomic conditions, this baseless perspective of inequality being cured through access to better teachers is a treacherous accountability proposition that seems to shift responsibility from other sources of injustice to a playing field where many issues compete for the attention of the teacher.

\section{Conclusion}

In this article, we have looked at the reaction of the German education system to the findings of the PISA 2000 by focusing on some of the measures taken in terms of improving school development through the setting of national educational standards and an assessment framework that operates at three levels (school, state, national) to monitor outcomes based on those standards. Along the way, we have touched upon a few of the issues related to validation of those standards and the hierarchical test-based accountability system (VERA, national standardised assessments, and PISA) that operates within and without the system to 
keep track of student performance at primary and lower secondary levels. The PISA shock transformed the education landscape in Germany, with the biggest change being the fundamental shift from an input-focused approach base on curriculum teaching to an outputoriented competence-based system where test-based accountability became the new modus operandi. We have also looked at the SINUS teacher-training programme which was set up to cater for the professional development of teachers at primary and secondary levels.

These changes have played an important role in shaping an education system in Germany that has seen major improvements, as can be seen from the country's rise in PISA rankings since 2000. While OECD countries like Finland, which featured prominently in the study in the early years of PISA, have seen their progression slow down and even falter, Germany's education system has been slowly but surely recovering from the shock. However, one has to be reminded that reforms in Germany have been implemented along recommendations coming from the OECD, which runs the PISA study, and one could not be blamed for thinking that the scenario could have been different had German policymakers not followed such guidelines.

\section{Acknowledgement}

The author is grateful to Catarina Correia and Kate Boldry of the UCL Institute of Education for feedback on an earlier draft of this article.

\section{Financial Support}

The author was supported by a UK Foreign, Commonwealth and Development Office Chevening scholarship. 


\section{References}

Bach, A., Wurster, S., Thillmann, K., Pant, H.A. \& Thiel, F. (2014). Vergleichsarbeiten und schulische Personalentwicklung - Ausmaß und Voraussetzungen der Datennutzung [Comparative work and school personnel development - extent and requirements for data use]. Zeitschrift für Erziehungswissenschaft, 17, $61-84$.

Batzdorfer, V. \& Kullmann, H. (2016). Neue Vielfalt im Klassenzimmer - Multiprofessionelle Kooperation als Herausforderung inklusiver Schulen [New diversity in the classroom - multiprofessional cooperation as a challenge for inclusive schools]. Diagonal: Vielfalt als Chance, 37, 263 $-280$.

Bennett, R. (2006). Foreword. In G. Matters, Using Data to Support Learning in Schools: Students, Teachers, Systems (pp. iii-v). Camberwell, Vic: ACER.

Betebenner, D.W., Shang, Y., Xiang, Y., Zhao, Y. \& Yue, X. (2008). The impact of performance level misclassification on the accuracy and precision of percent at performance level measures. Journal of Educational Measurement, 45, 119 - 137.

Böttcher, W. \& Keune, M. (2012). Externe Evaluation und die Steuerung der Einzelschule: Kontrolle oder Entwicklung [External evaluation and steering of schools: Control or development]? In S. Ratermann \& S. Stöbe-Blossey (Eds.), Governance von Schul- und Elementarbildung (pp. 63 80). Wiesbaden: Springer VS.

Breakspear, S. (2012). The policy impact of PISA: An exploration of the normative effects of international benchmarking in school system performance. OECD Education Working Papers, 71.

Brophy, J. \& Good, T.L. (1984). Teacher behavior and student achievement. Occasional Paper, 73, The Institute for Research on Teaching: Michigan State University.

Bund-Länder-Kommission für Bildungsplanung (BLK) (1997). Gutachten zur Vorbereitung des Programms "Steigerung der Effizienz des mathematisch-naturwissenschaftlichen Unterrichts." Materialien zur Bildungsplanung und zur Forschungsförderung: Vol. 60 [Review to prepare the programme "Enhancing the efficacy of mathematics and science teaching." Materials for planning in education and research funding]. Bonn, Germany: BLK, Geschäftsstelle. 
Bybee, R.W., McCrae, B. \& Laurie, R. (2009). PISA 2006: An assessment of scientific literacy. Journal of Research in Science Teaching, 46(8), $865-883$.

Carvalho, L.M. (2012). The fabrications and travels of a knowledge-policy instrument. European Educational Research Journal, 11(2), $172-188$.

Cizek, G.J. \& Bunch, M.B. (2007). Standard setting: A guide to establishing and evaluating performance standards on test. Thousand Oaks: Sage.

Coburn, C.E. \& Turner, E.O. (2011). Research on data use: A framework and analysis. Measurement: Interdisciplinary Research and Perspectives, 9(4), 173 - 206.

Cochran-Smith, M., Carney, M.C., Keefe, E.S., Burton, S., Chang, W.-C., Fernández, M.B., Miller, A.F., Sánchez, J.G. \& Baker, M. (2018). Democratic accountability in teacher education: Now more than ever. Teacher Education and Practice, 31(2), 178 - 206.

Dalehefte , I.-M., Wendt, H., Köller, O., Wagner, H., Pietsch, M., Fischer, C. \& Bos, W. (2014). Bilanz von neun Jahren SINUS an deutschen Grundschulen: Evaluation im Rahmen der TIMSS 2011 Erhebung [Taking stock after nine years of SINUS at elementary school in Germany: An evaluation in the context of TIMSS 2011]. Zeitschrift für Pädagogik, 60(2), 245 - 263.

Darling-Hammond, L. (1998). Teachers and teaching: Testing policy hypotheses from a national commission report. Educational Researcher, 27(1), 5-15.

Darling-Hammond, L. \& Sykes, G. (Eds.). (1999). Teaching as the learning profession: Handbook of policy and practice. San Francisco, CA: Jossey Bass.

Decker, D.M. \& Bolt, S.E. (2008). Challenges and opportunities for promoting student achievement through large-scale assessment results: Research, reflections, and future directions. Assessment for Effective Intervention, 34, 43 - 51.

Demski, D. \& Racherbäumer, K. (2017). What data do practitioners use and why? Evidence from Germany comparing schools in different contexts. Nordic Journal of Studies in Educational Policy, 3(1), $82-94$.

Emons, W.H.M., Sijtsma, K. \& Meijer, R.R. (2007). On the consistency of individual classification using short scales. Psychological Methods, 12, $105-120$.

Ercikan, K. \& Julian, M. (2002). Classification accuracy of assigning student performance to 
proficiency levels: Guidelines for assessment design. Applied Measurement in Education, 15, $269-294$.

Ertl, H. (2006). Educational standards and the changing discourse on education: The reception and consequences of the PISA study in Germany. Oxford Review of Education, 32(5), 619 - 634.

Feuer, M. (2013). Validity issues in international large-scale assessments: 'truth' and 'consequences'. In M. Chatterji (Ed.), Validity and Test Use: An International Dialogue on Educational Assessment, Accountability and Equity (pp. 197-215). Emerald Group Publishing: Bingley.

Fleischman, S. (2009). User-driven research in education: A key element promoting evidencebased education. In W. Böttcher, J. N. Dicke \& H. Ziegler (Eds.), Evidenzbasierte Bildung. Wirkungsevaluation in Bildungspolitik und pädagogischer Praxis (pp. 69 - 82). Münster: Waxmann.

Frühwacht, A. (2012). Bildungsstandards in der Grundschule. Bildungsstandards und Vergleichsarbeiten aus Sicht von deutschen und finnischen Lehrkräften [Educational standards in primary school. Educational standards and comparative work from the perspective of German and Finnish teachers]. Bad Heilbrunn: Klinkhardt.

Fuchs, J.A. (2017). "It takes a village"- (Catholic) Education in the $21^{\text {st }}$ century. In P. Siljander, K. Kontio \& E. Pikkarainen (Eds.), Schools in Transition - Linking Past, Present, and Future in Educational Practice (pp. 229 - 239). Leiden, Boston: Brill|Sense.

Grek, S. (2009). Governing by numbers: The PISA 'effect' in Europe. Journal of Education Policy, $24(1), 23-37$.

Gruber, K.H. (2006). The German "PISA-shock": Some aspects of the extraordinary impact of the OECD's PISA study on the German education system. In H. Ertl (Ed.), Cross-national attraction: Accounts from England and Germany (pp. 195 - 208). Oxford, England: Symposium Books.

Hanberger, A. (2014). What PISA Intends to and Can Possibly Achieve: A Critical Programme Theory Analysis. European Educational Research Journal, 13(2), 167 - 180.

Henry, M., Lingard, B., Rizvi, F. \& Taylor, S. (2001). The OECD, globalisation, and education policy (Issues in higher education). Amsterdam; London: Pergamon for the International Association 
of Universities Press.

Herzog, W. (2013). Bildungsstandards [Educational standards]. Stuttgart: Kohlhammer.

Institut zur Qualitätsentwicklung im Bildungswesen (IQB). VERA - An overview. Available at: https://www.iqb.hu-berlin.de/vera [accessed on 23 February 2020].

Jürgens, E. (2004). Pädagogische Implikationen der KMK-Entwürfe für Bildungsstandards [Pedagogical implications of the KMK drafts of education standards]. In J. Schlömerkemper (Ed.), Bildung und Standards (pp. 48 - 65). Weinheim, Germany: Juvena.

Kane, M.T. (1992). Quantitative methods in psychology: An argument-based approach to validity. Psychological Bulletin, 112, $527-535$.

Kane, M.T. (2009). Validating the interpretations and uses of test scores. In R.W. Lissitz (Ed.), The concept of validity: Revisions, new directions, and applications (pp. 39 - 64). Charlotte: Information Age.

Klieme, E., Avenarius, H., Blum, W., Döbrich, P., Gruber, H., Prenzel, M. et al. (2003). Zur Entwicklung nationaler Bildungsstandards [Regarding the development of National Education Standards]. Berlin, Germany: Bundesministerium für Bildung und Forschung.

Kruger, J. \& Dunning, D. (1999). Unskilled and Unaware of It: How Difficulties in Recognizing One's Own Incompetence Lead to Inflated Self-Assessments. Journal of Personality and Social Psychology, 77(6), $1121-1134$.

Kühle, B. \& van Ackeren, I. (2012). Wirkungen externer Evaluationsformen für eine evidenzbasierte Schul- und Unterrichtsentwicklung [Effects of external evaluation for evidence-based school improvement]. In M. Ratermann \& S. Stöbe-Blossey (Eds.), Governance von Schul- und Elementarbildung (pp. $45-62$ ). Wiesbaden: VS

Kultusministerkonferenz (KMK). (2002). PISA 2000 - Zentrale Handlungsfelder: Zusammenfassende Darstellung der laufenden und geplanten Maßnahmen [PISA 2000 Central fields of action: Summary of current and future measures]. Available at: https://bit.ly/2VpYLi9 [accessed on 24 February 2020].

Kultusministerkonferenz (KMK). (2004). Standards für die Lehrerbildung: Bildungswissenschaften [Standards for teacher education: Educational sciences]. Available at: https://bit.ly/2SKVoAk 
[accessed on 21 February 2020].

Kultusministerkonferenz (KMK). (2016). The Education System in the Federal Republic of Germany 2016/2017. A description of the responsibilities, structures and developments in education policy for the exchange of information in Europe. Available at: https://bit.ly/2T9yzH3 [accessed on 27 February 2020].

Lee, W.-C. (2010). Classification consistency and accuracy for complex assessments using item response theory. Journal of Educational Measurement, 47, 1-17.

Linn, R.L. (2000). Assessments and accountability. Educational Researcher, 29(2), 4 - 16.

Lundahl, C. \& Waldow, F. (2009). Standardisation and 'Quick Languages': the shape-shifting of standardised measurement of pupil achievement in Sweden and Germany, Comparative Education, 45(3), $365-385$.

Maier, U., Bohl, T., Kleinknecht, M. \& Metz, K. (2012). Impact of mandatory testing system and school context factors on teachers' acceptance and usage of school performance feedback data. Journal for Educational Research Online/Journal für Bildungsforschung Online, 3, 62-93.

Martens, K. (2007). How to become an influential actor - The 'comparative turn' in OECD education policy. In Martens, K., Rusconi, A. \& Leuze, K. (Eds), New Arenas of Education Governance - The Impact of International Organizations and Markets on Education Policy Making (pp. 40 - 56). Basingstoke: Palgrave Macmillan.

Martens, K. \& Niemann, D. (2013). When do numbers count? The differential impact of the PISA rating and ranking on education policy in Germany and the US. German Politics, 22(3), 314 332.

Messick, S. (1995). Validity of psychological assessment: Validation of inferences from persons' responses and performances as scientific inquiry into score meaning. American Psychologist, $50,741-749$.

Morris, A. (2011). Student Standardised Testing: Current Practices in OECD Countries and a Literature Review / Allison Morris (OECD education working papers; no. 65). Paris: OECD Publishing.

Neumann, K., Fischer, H. \& Kauertz, E. (2010). From PISA to educational standards: The impact of 
large-scale assessments on science education in Germany. International Journal of Science and Mathematics Education, 8(3), 545 - 563.

Niemann, D. (2016). Germany. In L. Volante (Ed.), The intersection of international achievement testing and educational policy: Global perspectives on large-scale reform. New York: Routledge.

Niemann, D., Martens, K. \& Teltemann, J. (2017). PISA and its consequences: Shaping education policies through international comparisons. European Journal of Education, 52(2), 175 - 183.

Nóvoa, A. \& Yariv-Mashal, T. (2003). Comparative Research in Education: A mode of governance or a historical journey? Comparative Education, 39(4), $423-438$.

O'Neill, O. (2013). Intelligent accountability in education. Oxford Review of Education, 39(1), 4 16.

Organisation for Economic Co-operation and Development (OECD). Programme for International Student Assessment. Available at: https://www.oecd.org/pisa/ [accessed on 27 February 2020].

Organisation for Economic Co-operation and Development (OECD) (2013). Synergies for better learning an international perspective on evaluation and assessment. (OECD reviews of evaluation and assessment in education). Paris: OECD.

Osborn M. (2006). Changing the context of teachers' work and professional development: a European perspective. International Journal of Educational Research, 45, pp. $242-253$.

Ostermeier, C., Prenzel, M. \& Duit, R. (2010). Improving science and mathematics instruction: The SINUS Project as an example for reform as teacher professional development. International Journal of Science Education, 32(3), $303-327$.

Ozga, J. (2012). Assessing PISA. European Educational Research Journal, 11(2), 166 - 171.

Pant, H.A., Tifflin-Richards, S.P. \& Stanat, P. (2017). Standard Setting: Bridging the Worlds of Policy Making and Research. In S. Blömeke \& J.-E. Gustafsson (Eds.), Standard setting in education: The Nordic countries in an international perspective (pp. 49 - 68). (Methodology of educational measurement and assessment). 
Peske, H. \& Haycock, K. (2006). Teaching inequality: How poor and minority students are shortchanged on teacher quality: A report and recommendations by the Education Trust. Washington, DC: Education Trust.

Pizmony-Levy, O. (2013). Testing for All: The Emergence and Development of International Assessments of Student Achievement, 1958-2012 (PhD dissertation). Indiana University (ED562896).

Prenzel, M., Rost, J., Senkbeil, M., Häußler, P. \& Klopp, A. (2001). Naturwissenschaftliche Grundbildung: Testkonzeption und Ergebnisse [Scientific literacy: Test conception and results]. In J. Baumert, E. Klieme, M. Neubrand, M. Prenzel, U. Schiefele, W. Schneider, et al. (Eds.), PISA 2000. Basiskompetenzen von Schülerinnen und Schülern im internationalen Vergleich [PISA 2000: Basic compencies of students in international comparison] (pp. 191 -248). Opladen, Germany: Leske + Budrich.

Prenzel, M., Carstensen, C.H., Senkbeil, M., Ostermeier, C. \& Seidel, T. (2005). Wie schneiden SINUS-Schulen bei PISA ab [How do SINUS schools do in PISA]? Zeitschrift für Erziehungswissenschaft, 8(4), $540-561$.

Prenzel, M., Friedrich, A. \& Stadler, M. (Eds.). (2009a). Von SINUS lernen-Wie Unterrichtsentwicklung gelingt [Learning from SINUS - How the development of teaching succeeds]. Seelze -Velber, Germany: Kallmeyer.

Prenzel., M., Stadler, M., Friedrich, A., Knickmeier, K. \& Ostermeier, Ch. (2009b). Increasing the efficiency of mathematics and science instruction (SINUS) - A large scale teacher professional development programme in Germany. Kiel: Leibniz-Institute for Science Education.

Raidt, T. (2010). Bildungsreformen nach PISA: Paradigmenwechsel und Wertewandel [Educational reforms according to PISA: paradigm shift and change in values] (PhD dissertation). Heinrich-Heine University Düsseldorf. Düsseldorf: Tredition. Available at: https://bit.ly/2SQMr8C [accessed on 23 February 2020].

Richter, D., Böhme, K., Becker, M., Pant, H.A. \& Stanat, P. (2014). Überzeugungen von Lehrkräften zu den Funktionen von Vergleichsarbeiten: Zusammenhänge zu Veränderungen im Unterricht und den Kompetenzen von Schülerinnen und Schülern [Teachers' beliefs about the functions of comparative work: Relationships to changes in teaching and the skills of students]. Zeitschrift für 
Pädagogik, 60, $225-244$.

Roberts, D.A. (2007). Scientific literacy/science literacy. In S.K. Abell \& N.G. Lederman (Eds.), Handbook of research on science education (pp. 729 - 780). Mahwah, NJ: Lawrence Erlbaum.

Sadler, T.D. \& Zeidler, D.L. (2009). Scientific literacy, PISA and socioscientific discourse: Assessment for progressive aims of science education. Journal of Research in Science Teaching, 46(8), 909 $-921$.

Sälzer, C. \& Prenzel, M. (2014). Looking back at five rounds of PISA: Impacts on teaching and learning mathematics in Germany. Solsko Polje (The School Field), 25(5/6), 53 - 72.

Sälzer, C. \& Prenzel, M. (2018). Policy Implications of PISA in Germany - The Case of Teacher Education. In L. Volante (Ed.), The PISA effect on global educational governance (pp. 109 125). New York: Routledge.

Sammons, P. (1999). School effectiveness: Coming of age in the twenty-first century. Lisse, The Netherlands: Swets and Zeitlinger.

Schönig, W. (2007). Contemporary challenges for catholic schools in Germany. In G.R. Grace \& J. O'Keefe (Eds.), International handbook of catholic education - Challenges for school systems in the 21st century (pp. 481 - 499). New York, NY: Springer.

Schulniveau (2014, May 5). Das Ziel ist verfehlt [The goal has been missed]. Deutschlandfunk Kultur. Available at: https://bit.ly/2T1tRJO [Accessed on 23 February 2020].

Terhart, E. (Ed.). (2000). Perspektiven der Lehrerbildung in Deutschland. Abschlussbericht der von der Kultusministerkonferenz eingesetzten Kommission [Perspectives of teacher education in Germany: Final report of the commission appointed by the conference of educational ministers in Germany]. Weinheim, Germany: Beltz.

Terhart, E. (2001). Lehrerberuf und Lehrerbildung: Forschungsbefunde, Problem-analysen, Reformkonzepte [Teaching profession and teacher education: Research findings, problem analyses, reform concepts]. Weinheim, Germany: Beltz.

Volante, L. (Ed.). (2016). The intersection of international achievement testing and educational policy: Global perspectives on large-scale reform. New York, NY: Routledge.

Walke, J. (2007). Die Zweite Phase der Lehrerbildung: Ein Überblick über Stand, Problemlagen und 
Reformtendenzen. Eine Expertise für den Wissenschaftlichen Beirat des Aktionsprogramms "Neue Wege in der Lehrerausbildung" des Stifterverbandes für die Deutsche Wissenschaft /Mercator Stiftung Mercator [The second phase of teacher education: An overview of the current state, problems and trends of reforms. An expertise for the scientific advisory board of the programme "New paths in teacher education" of the foundation for German Science /Mercator]. Schriftenreihe zur Lehrerbildung : Bd. III. Essen, Germany: Edition Stifterverband.

Wiseman, A.W. (2013). Policy responses to PISA in comparative perspective. In H.-D. Meyer \& A. Benavot (Eds.), PISA, power, and policy: The emergence of global educational governance (pp. 303 - 322). Oxford, England: Symposium Books.

Wurster, S., Richter, D., Schliesing, A. \& Pant, H.A. (2013). Nutzung unterschiedlicher Evaluationsdaten an Berliner und Brandenburger Schulen. Rezeption und Nutzung von Ergebnissen aus Schulinspektion, Vergleichsarbeiten und interner Evaluation im Vergleich [Use of different evaluation data at schools in Berlin and Brandenburg. Reception and use of results from school inspection, comparative work and internal evaluation in comparison]. Die Deutsche Schule, 12 (Suppl.), $19-50$.

Wyse, A.E. (2010). The potential impact of not being able to create parallel tests on expected classification accuracy. Applied Psychological Measurement, 35, 110 - 126.

Zhang, B. (2010). Assessing the accuracy and consistency of language proficiency classification under competing measurement models. Language Testing, 27, 119- 140. 